\title{
PENDIDIKAN MULTIPLE INTELLIGENCES PADA ANAK USIA DINI
}

\author{
Sulfa Nurrachma \\ Guru TK PAUD Wihdatul Ummah Kota Ternate
}

\begin{abstract}
Programs such as education and learning that took place at this time, therefore, must be directed or oriented to individual learners. The fact shows that the educational program of the present day more done by making a generalization of the potential and abilities of students. Multiple intelligences can use for teaching in early childhood education. It cover integrated learning without separated others. Teacher can teach them by using some approaches. Using Multiple Intelligences in early childhood shows the competences of students. The parents can guide their children with focusing on children's competences.
\end{abstract}

\section{PENDAHULUAN}

Pendidikan bagi anak usia dini memang pendidikan yang paling dasar bagi anak. Pada tahap ini orang tua harus benar-benar memperhatikan pendidikan bagi anaknya. Baik dalam memilih lembaga pendidikan bagi sang anak atau pun memilih untuk mendidik sendiri sang anak dirumah. Dalam pendidikan anak usia dini hendaknya memperhatikan kecerdasan yang dimiliki oleh anak. Karena kecerdasan anatara satu anak dengan yang lain berbeda. Orang tua maupun pendidik anak usia dini harus mengenali kecerdasan yang dimiliki anak agar dapat mengarahkan dan mengembangkan kecerdasan yang dimiliki anak secara maksimal. Pendidikan pada dasarnya merupakan suatu proses pengembangan potensi individu. Melalui pendidikan, potensi yang dimiliki oleh individu akan diubah menjadi kompetensi. Kompetensi mencerminkan kemampuan dan kecakapan individu dalam melakukan suatu tugas atau pekerjaan.Tugas pendidik atau guru dalam hal ini adalah memfasilitasi anak didik sebaga individu untuk dapat mengembangkan potensi yang dimiliki menjadi kompetensi sesuai dengancita-citanya.

Program pendidikan dan pembelajaran seperti yang berlangsung saat ini oleh karenanya harus lebih diarahkan atau lebih berorientasi kepada individu peserta didik. Kenyataan menunjukkan bahwa program pendidikan yang berlangsung saat ini lebih banyak dilaksanakan dengan cara membuat generalisasi terhadap potensi dan kemampuan siswa. Hal ini disebabkan karena kurangnya pemahaman pendidik tentang karakteristik individu. Muncul keluhan dari pendidik atau guru bahwa mereka merasa bahwa menjelaskan sejelas-jelasnya tetapi ada saja anak didik yang tidak dapat memahami pelajaran dengan baik.Setiap kali orang belajar pasti melibatkan pikirannya dan didalam pikiran tersebut ada kecerdasan.Salah satu temuan yang sangat bermanfaat adalah bahwa setiap individu memiliki tidak hanya memiliki satu kecerdasan tetapi lebih yaitu disebut juga multiple intelligences atau kecerdasan ganda. 


\section{KAJIAN PUSTAKA}

\section{A. MULTIPLE INTELLIGENCES}

\section{$>$ Pengertian Intelligence (Kecerdasan)}

Kecerdasan merupakan salah satu anugerah besar dari Allah SWT kepada manusia dan menjadikannya sebagai salah satu kelebihan manusia dibandingkan dengan makhluk lainnya. Dengan kecerdasannya, manusia dapat terus menerus mempertahankan dan meningkatkan kualitas hidupnya yang semakin kompleks, melalui proses berfikir dan belajar secara terus menerus. Selain manusia, sesungguhnya hewan pun diberikan kecerdasan namun dalam kapasitas yang sangat terbatas. Oleh karena itu untuk mempertahankan keberlangsungan hidupnya lebih banyak dilakukan secara instingtif (naluriah). David Weschler memberikan rumusan tentang kecerdasan sebagai suatu kapasitas umum dari individu untuk bertindak, berpikir rasional dan berinteraksi dengan lingkungan secara efektif.

Menurut beberapa teori, kecerdasan atau intelegensi terkait dengan cara individu berbuat, apakah berbuat dengan cara yang cerdas atau kurang cerdas atau tidak cerdas sama sekali. Suatu perbuatan cerdas ditandai oleh perbuatan yang cepat dan tepat. Cepat dan tepat dalam memahami suatu masalah, menarik kesimpulan serta mengambil keputusan atau tindakan. Para ahli memberikan pengertian yang berbada tentang kecerdasan. C.P. Chaplin mengartikan kecerdasan sebagai kemampuan menghadapi dan menyesuaikan diri terhadap situasi baru secara cepat dan efektif. Sementara itu, Anita E. Woolfolk mengemukakan bahwa menurut teori lama, kecerdasan meliputi tiga pengertian, yaitu :

1) kemampuan untuk belajar.

2) keseluruhan pengetahuan yang diperoleh; dan

3) kemampuan untuk beradaptasi dengan dengan situasi baru atau lingkungan padaumumnya.

Jika kita merujuk ke pendapat Howard Gardner, dia memberikan definisi tentang kecerdasan sebagai berikut:

1) Kecakapan untuk menyelesaikan masalah yang dihadapi dalam kehidupan.

2) Kecakapan untuk mengembangkan masalah untuk dipecahkan.

3) Kecakapan untuk membuat sesuatu atau melakukan sesuatu yang bermanfaatdi dalam kehidupan.

Gardner juga mendefinisikan bahwa inteligensi itu merupakan kemampuan untuk memecahkan persoalan dan menghasilkan produk dalam suatu setting yang bermacammacam dan dalam situasi yang nyata. Berdasarkan pengertian dapat dipahami bahwa inteligensi bukanlah kemampuan seseorang untuk menjawab soal-soal tes $I Q$ dalam ruang tertutup yang terlepas dari lingkungannya. Akan tetapi, inteligensi memuat kemampuan seseorang untuk memecahkan persoalan yang nyata dan dalam situasi yang bermacam-macam. Gardner menekankan pada kemampuan memecahkan persoalan yang nyata, karena seseorang memiliki kemampuan inteligensi yang tinggi 
bila ia dapat menyelesaikan persoalan hidup yang nyata, bukan hanya dalam teori. Semakin seseorang terampil dan mampu menyelesaikan persoalan kehidupan yang situasinya bermacam-macam dan kompleks, semakin tinggi inteligensinya. Pemikiran Gardner tentang kecerdasan merupakan sebuah kritikan pada pemikiran Alfred Bined tentang intelligence dan tes IQ. Gardner menolak akan tentang adanya tes IQ yang fenomenal di Barat hanya terbatas pada menjawad soal-soal dalam lembaran-lembaran saja, sebab menurutnya kecerdasan adalah bagaimana keterampialan seseorang dalam memecahkan persoalan sehari-harinya yang dilaksanakan secara terus menerus.

\section{Pengertian Multiple Intelligences (Kecerdasan Ganda)}

Multiple Intelligences adalah istilah atau teori dalam kajian tentang ilmu kecerdasan yang memiliki arti "kecerdasan ganda" atau "kecerdasan majemuk". Teori ini ditemukan dan dikembangkan oleh Howard Gardner, seorang psikolog perkembangan dan profesor pendidikan dari Graduate School Of Education, Harvad University, Amerika Serikat. Dia juga adalah penulis Frames of Mind: The Theory of Multiple Intelligences (Basic Books, 1983/1993), Multiple Intelligences: The Theory in Practicelntelligence Reframed: Multiple Intelligences for the 21st Century (Basic'Books, 1993), dan (Basic Books, 1993). Saat ini dia juga salah satu direktur Project Zero di Harvard Graduate School of Education. Project Zero adalah pusat penelitian dan pendidikan yang mengembangkan cara belajar, berpikir, dan kreativitas dalam mempelajari suatu bidang bagi individu dan institusi.

Di dalam teorinya Gardner menjelaskan bahwa setiap orang memilki bermacammacam kecerdasan, tetapi dengan kadar pengembangan yang berbeda antara kecerdasan yang satu dengan kecerdasan lainnya. Pengertian inteligensi Gardner ini berbeda dengan pengertian yang dipahami sebelumnya. Sebelum Gardner, pengukuran IQ (Intelligence Question) seseorang didasarkan pada tes IQ saja, yang hanya menonjolkan kecerdasan matematis-logis dan linguistik. Sehingga kurang memperhatikan kecerdasan pada bidang yang lain. Penemuan Gardner tentang inteligensi seseorang telah mengubah konsep kecerdasan. Inteligensi seseorang dapat dikembangkan melalui pendidikan dan jumlahnya banyak. Secara jelasnya Gardner mengungkapkan bahwa tidak ada anak bodoh atau pintar. Yang ada, anak yang menonjol dalam salah satu atau beberapa jenis kecerdasan tersebut. Dengan demikian, dalam menilai dan menstimulasi kecerdasan anak, orang tua dan guru selayaknya dengan jeli dan cermat merancang sebuah metode khusus. Dalam menstimulasi kecerdasan anak, dapat dikatakan, kecerdasan tertentu bisa jadi diasah agar lebih terampil.

Esensi teori multiple intelligences menurut Gardner adalah menghargai keunikan setiap orang, berbagai variasi cara belajar, mewujudkan sejumlah model untuk menilai mereka, dan cara yang hampir tak terbatas untuk mengaktualisasikan diri didunia ini dalam bidang tertentu yang akhirnya diakui. Menurut hasil penelitiannya, Gardner menyatakan bahwa di dalam diri setiap orang terdapat delapan jenis kecerdasan dintaranya seperti kecerdasan logikamatematika, linguistik (berbahasa), visual-spasial, kinestetik (gerak tubuh), musikal, interpersonal, intrapersonal, dan naturalis. Kedelapan kecerdasan tersebut bisa saja dimiliki oleh setiap individu, hanya saja dalam taraf 
berbeda. Selain itu, kecerdasan ini juga tidak berdiri sendiri, terkadang bercampur dengan kecerdasan lain.

\section{$>$ Macam-Macam Multiple Intelligences}

Menurut Howard Gardner seorang pencetus teori Multiple intelligences, terdapat sembilan jenis kecerdasan manusia yaitu:

\section{Kecerdasan matematika dan logika}

Kecerdasan logis matematis memuat kemampuan seseorang dalam berfikir secara induktif dan deduktif, berfikir menurut aturan logika, memahami dan menganalisis pola angka-angka, serta memecahkan masalah dengan menggunakan kemampuan berfikir. Kemampuan ini bisa diasah lewat permainan yang menggunakan angka-angka, misalnya bermain. Untuk merangsang serta mengoptimalkan kecerdasan logismatematis, anda harus mengondisikan otak anak agar siap menerima materi dengan situasi dan cara pembelajaran yang menyenangkan.

\section{Kecerdasan bahasa}

Kecerdasan bahasa memuat kemampuan seseorang untuk menggunakan bahasa dan kata-kata, baik secara tertulis maupun lisan, dalam berbagai bentuk yang berbeda untuk mengekspresikan gagasan-gagasannya. Kecerdasan bahasa biasanya tampak dalam beberapa aspek, seperti retorika, yaitu kemampuan menggunakan bahasa untuk meyakinkan orang lain; mnemonik, yaitu kemampuan untuk membantu orang lain mengingat berbagai macam informasi; penjelasan, yaitu kemampuan untuk menjelaskan; dan metalinguistik, yaitu kemampuan menggunakan bahasa untuk membuat refleksi atas bahasa itu sendiri. Ada beberapa cara untuk meningkatkan kemampuan berbahasa pada anak. Selain mengajak bicara, membaca cerita, dan menyanyi, anda dapat juga memasukkannya kedalam aktivitas drama yang kerap digelar oleh sanggar kesenian anak.

\section{Kecerdasan visual spasial}

Kecerdasan visual-spasial memuat kemampuan seseorang untuk memahami secara lebih mendalam dalam hubungan antara objek dan ruang. Peserta didik ini memiliki kemampuan, misalnya untuk menciptakan imajinasi bentuk dalam pikirannya atau kemampuan untuk menciptakan bentuk-bentuk tiga dimensi seperti dijumpai pada orang dewasa yang menjadi pemahat patung atau arsitektur suatu bangunan. Kemampuan membayangkan suatu bentuk nyata dan kemudian memecahkan berbagai masalah sehubungan dengan kemampuan ini adalah hal yang menonjol pada jenis kecerdasan visual-spasial. Peserta didik yang demikian akan unggul, misalnya dalam permainan mencari jejak pada suatu kegiatan kepramukaan. Kemampuan meningkatkan kecerdasan spasial bisa dilakukan sedini mungkin dengan belajar mengamati bendabenda dalam berbagai bentuk, menemukan cara-cara untuk keluar dari suatu ruangan hanya dengan membayangkannya, menggambarkan apa yang dibayangkan, menikmati gambar-gambar abstrak, belajar dengan menggunakan diagram, menyusun atau menggabungkan bentuk-bentuk bangun tertentu dan menghasilkan bentuk bangun yang baru. 
4. Kecerdasan musikal

Kecerdasan musikal memuat kemampuan seseorang peka terhadap suara-suara nonverbal yang berada di sekelilingnya, termasuk dalam hal ini adalah nada dan irama. Peserta didik jenis ini cenderung senang sekali mendengarkan nada dan irama yang indah, entah melalui senandung yang dilagukan sendiri, mendengarkan tape recorder, radio, pertunjukan orkestra, atau alat musik yang dimainkannya sendiri. Mereka juga lebih mudah mengingat sesuatu dengan mengekspresikan gagasan-gagasan apabila dikaitkan dengan musik. Kecerdasan musik pada anak pun dapat dirangsang sejak dini. Anak-anak diajarkan melalui irama dan melodi. Semua bisa dipelajari dengan mudah, bila hal itu dinyanyikan atau diberi aba-aba dengan ketukan menurut irama. Anak diperkenalkan dengan lagu-lagu dan ritme. Pengenalan lagu-lagu harus dilakukan secara bertahap dan sesuai usia.

\section{Kecerdasan kinestetik}

Kecerdasan kinestetik memuat kemampuan sesorang untuk secara aktif menggunakan bagian-bagian atau seluruh tubuhnya untuk berkomunikasi dan memecahan berbagai masalah. Hal ini dapat dijumpai pada pesrta didik yang unggul pada salah satu cabang olahraga, seperti bulu tangkis, sepak bola, tenis, renang, dan sebagainya, atau bisa pula tampil pada peserta didik yang pandai menari, terampil bermain akrobat, atau unggul dalam bermain sulap. Pengoptimalan kecerdasan kinestetik dapat dilakukan dengan berbagai permaianan yang berorientasi pada kegiatan bergerak secara fisik. Contoh permainan ini yaitu,n menari, bermain peran, melompat, menari, main dorong-dorongan, permainan bola dll.

\section{Kecerdasan interpersonal}

Kecerdasan intrapersonal menunjukkan kemampuan seseorang untuk peka terhadap perasaan orang lain. Mereka cenderung untuk memahami dan berinteraksi dengan orang lain sehingga mudah bersosialisasi dengan lingkungan di sekelilingnya. Kecerdasan semacam ini juga sering disebut sebagai kecerdasan sosial, yang selain kemampuan menjalin persahabatan yang akrab dengan teman, juga mencangkup kemampuan seperti memimpin, mengorganisasi, menangani perselisihan antar teman, memperoleh simpati dari peserta didik yang lain, dan sebagainya. Untuk mengoptimalkan kecerdasan ini anda dapat memberikan permainan-permainan yang bisa memunculkan berbagai perasaan. Misalnya menunjukkan perasaan sedih, gembira, kesal, kecewa, bahagia dan lain-lain. Sebelumnya anda harus menunjukkan dulu berbagai perasan emosi tersebut, jelaskanlah situasi-situasi yang menimbulkannya, lalu anak akan memainkan peran sedang sedih, kesal, dan lain-lain.

\section{Kecerdasan intrapersonal}

Kecerdas interpersonal menunjukkan kemampuan seseorang untuk peka terhadap perasaan dirinya sendiri. la cenderung mampu untuk mengenali berbagai kekuatan maupun kelemahan yang ada pada dirinya sendri. Peserta didik semacam ini senang melakukan intropeksi diri, mengoreksi kekurangan maupun kelemahannya, kemudian mencoba untuk memperbaiki diri. Beberapa diantaranya cenderung menyukai kesunyian dan kesendirian, merenung, dan berdialog dengan dirinya sendiri. Permainan 
yang dapat merangsang perkembangan kecerdasan interpersonal yaitu, misalnya bermain pura-pura, bermain telepon, dll. dorong anak untuk melakukan aktifitas belajar kelompok.

\section{Kecerdasan naturalis}

Kecerdasan naturalis ialah kemampuan seseorang untuk peka terhadap lingkungan alam, misalnya senang berada dilingkungan alam yang terbuka, seperti pantai, gunung, cagar alam, atau hutan. Peserta didik dengan kecerdasan seperti ini cenderung suka mengobservasi lingkungan alam seperti aneka macam bebatuan, jenisjenis lapisan tanah, aneka macam flora dan fauna, benda-benda angkasa, dan sebagainya. Belajar dengan cara naturalis dapat dilakukan di perumahan yang aman, nyaman, asri, dekat dengan danau, dan bebas polusi, karena tidak dilewati kendaraan umum.

\section{Kecerdasan eksistensial}

Kecerdasan eksistensial sering dinilai sebagai bagian dari kecerdasan spiritual atau Spiritual Quetient (SQ). Kecerdasan ini kiranya harus dipandang sebagai sifat yang harus dikembangkan pada diri setiap anak, apa pun bakat dan kemampuannya demi memastikan bahwa pada pucaknya sang anak dapat menjadikan bakat serta kemampuannya itu untuk memperoleh kesuksesan dan kebahagiaan hidup.

\section{B. Penerapan Multiple Intelligences Pada Anak Usia Dini}

Pembahasan Multiple intelligences merupakan padan psikologis yang kemudian ditarik kedalam dunia pendidikan. Penarikan ini dimungkinkan sebab dunia pendidikan tidak dapat menghindari bahasan psikologis terutama prikologi perkembangan yang terkait pada penilaian kemampuan seseorang secara psikologis. Pendidikan merupakan sarana yang memfasilitasi seseorang untuk mengembangkan potensi yang dimilikinya. Setelah memperhatikan pemikiran Gardner tentang Multple Intelligencesnya, kita menyadari bahwa setiapa anak tidak ada yang bodoh atau dapat dikatakan setiap anak itu cerdas namun bentuk penginterpretasikannya yang berbada. Menurut Gardner, dalam diri seseorang terdapat delapan kecerdasan tersebut. Peran pendidikan dalam hal ini adalah mengembangkan potensi yang dimiliki oleh setiap anak melalui pengasahan dan pengajaran.

Pelaksanaannya dalam pendidikan melingkupi 3 hal yakni : input proses, dan output. Dalam input sekolah dengan memberi kesempatan sebesar-besarnya pada peserta didik untuk dapat mengeyam pendidikan dalam rangga mengembangkan dirinya. Sehingga batasan siswa yang masuk kesekolah bukan berdasarkan tes tulis yang disediakan sekolah untuk mengukur sebarapa pintar siswa yang akan bersekolah disekolah tersebut, tetapi dilihat dari berapa siswa yang mampu ditampung oleh sekolah tersebut. Pendidikan berbasis Multiple Intelligences ini lebih menekankan pada The Best Proses bukan the best input. Pelaksanaan pendidikan yang menekankan pada the best proses sangat dipengaruhi oleh elemen yang ada dalam proses itu, dalam hal ini yang terbasar perannya adalah guru atau pendidik. Guru dalam hal ini dituntut untuk lebih kretif dan inovatif dalam mengajar. Sehingga guru mampu membuka pintu-pintu 
kecerdasan yang dimiliki oleh siswa dan melalui pintu tersebutlah materi tersampaikan dengan baik. Guna mengetahui kecerdasan apa yang dimilikioleh seorang siswa maka digunakan alat tes yang disebut dengan MIR (Multiple intelligences research). Selain menggunakan MIR sebagai alay tes untuk mengetahui kecerdasan siswa dapat pula guru mengenali kecerdasan anak melalui kenakannnya dikelas sebagai nama yang disebutkan oleh Thomas Amstrong. Melalui hasil MIR guru merancang sekenario pembelajarannya, melaksanakannya, serta mengevaluasinya. Dalam perencanaan proses pembelajaran menyesuaikan dengan kecerdasan yang dimiliki siswa atau dapat dikatakan guru menyesuaikan gaya mengajarnya dengan gaja belajar siswanya, disinilah kreatifitas guru diuji. Ada banyak metode yang dapat digunakan guru dalam mengajar dalam pendidikan berbasis multiple intellegences ini misalnya mind mapping, Brainstorming, Diskusi, tanya jawab, presentasi, studi kasus, role play, karyawisata, pengamatan, sosiodrama, eksperiment, dll. Tentu saja penggunaan merode-metode tersebut harus menyesuaikan kondisi siswa. Penggunaan variasi metode dalam pembalajaran diharapkan mampu memotivasi siswa untuk terus dalam belajar, mengatasi kesulitannya dalam belajar serta memberikan pengalaman bagi diri siswa.

Dalam output lebih pada pemberian assesment (penilaian) yang menekankan pada sekuruh aspek dalam kognitif, afektif dan psikomotoriknya, yang dilakukan secara berkesinambungan dalam proses pembalajaran. Pendidikan berbasis Multiple Intelligences ini telah banyak digunakan di belahan dunia misalnya:

- The Ross School, East Hampton new York

- Key Learning Community, Irldianapolis, Indiana

- New City School, St. Louis, Missouri

- The Gardenr School, Vancouver

- The Cook Primary School, Canberra, Australia

Di Indonesia juga mulai diterapkan muali tahun 2003 berikut beberapa sekolah yang menggunakan pendidikan berbasis Multiple intelligences

- TK, SD, SMP YIMI Gresik

- TK, SD Mutiara ilmu Bangil

- SMP Muhammadiyah 1 Sidoarjo

- SMA Muhammadiyah 2 Sidoarjo

- TK, SD, SMP, MA YIMA Bondowoso

- TK, SD Al-Kausar Malang

- SD Lentera Insan, Jakarta, dll

\section{Strategi Pembelajaran Multiple Intelligences Pada Anak Usia Dini}

Saat ini para pendidik di seluruh dunia mencari cara efektif menerapkan teori ini sebagaimana mereka mencari cara untuk membantu siswa mengenali dan mengembangkan kekuatan mereka dan dalam prosesnya, mendapatkan cara mengajar baru yang lebih efektif." ( Dr. Howard Gardner, Tarreytown Conference Center, New York, 1994). Ada beberapa strategi dasar dalam kegiatan pembelajaran untuk mengembangkan kecerdasan ganda, yaitu: 
- Membangunkan /memicu kecerdasan, yaitu upaya untuk mengaktifkan indera dan menghidupkan kerja otak.

- Memperkuat kecerdasan, yaitu dengan cara member latihan dan memperkuat kemampuan membangunkan kecerdasan.

- Mengajarkan dengan /untuk kecerdasan ,yaitu upaya-upaya mengembangkan struktur pelajaran yang mengacu pada penggunaan kecerdasan ganda.

- Mentransfer kecerdasan, yaitu usaha memanfaatkan berbagai cara yang telah dilatihkan di kelas untuk memahami realitas di luar kelas atau pada lingkungan nyata.

Anak memiliki potensi berupa kecerdasan jamak. Kecerdasan anak akan berkembang secara optimal bila difasilitasi dengan baik dan benar, melalui strategi pembelajaran yang sesuai dengan karakteristik dan perkembangannya. Strategi pembelajaran yang dipilih oleh guru, hendaknya menekankan pada konsep pembelajaran yang mendidik.

Dalam merancang pembelajaran yang mendidik, guru perlu memperhatikan modalitas belajar anak. Ada empat modalitas belajar anak, yakni: (1) visual learner, (2) auditory learner, (3) tactile/kinesthetic learner, dan (4) global learner (DePorter, dan Mike H.,1992). Dalam modalitas yang pertama, anak cenderung mengalami pengalaman belajar dengan cara mengamati sesuatu. Anak lebih mengandalkan indera penglihatan dalam belajar. Dalam hal ini guru hendaknya memfasilitasi kebutuhan anak dengan cara menyediakan media visual yang menarik. Dalam modalitas yang kedua, anak lebih mengandalkan indera pendengarnya. Anak dengan mudah memahami sesuatu jika dia memperoleh kesempatan untuk mendengarkan berbagai bahan yang disajikan melalui media audio atau penjelasan langsung dari narasumber. Modalitas belajar yang ketiga, lebih mengandalkan pada pengalaman belajar dengan cara menyentuh, bergerak dan bekerja. Sementara modalitas yang keempat, anak dalam belajar menggunakan ketiga modalitas tersebut secara simultan.

Sementara ini, secara umum guru cenderung mengutamakan kecerdasan logicmathematic. Anak dikatakan cerdas jika anak mampu membaca, berhitung dan menulis dengan cepat, serta dapat menghafal berbagai kejadian. Strategi yang seperti itu cenderung menafikan potensi anak terutama yang ada di belahan otak kanan, sehingga anak menjadi kurang kreatif dalam memecahkan masalah. Padahal permasalahan kehidupan bersifat multi dimensi, yang tidak dapat ditinjau dari salah satu aspek saja. Berdasarkan hal ini guru perlu memilih strategi pembelajaran yang dapat memfasilitasi perkembangan otak belahan kiri dan kanan secara seimbang, sehingga semua aspek kecerdasan dapat berkembang secara optimal. Strategi yang dimaksud mengarah pada pembelajaran yang mendidik, yang dapat memberdayakan seluruh aspek perkembangan dan kecerdasan anak.

\section{Peran Multiple Intelegences Dalam Pembelajaran Anak Usia Dini}

Dalam dunia pendidikan anak usia dini, seorang pendidik dituntut mengoptimalkan potensi yang dimiliki peserta didik. Maka dalam pembelajaran di kelas seorang pendidik menerapkan berbagai model pembelajaran agar tercapainya tujuan pembelajaran. Namun, pencapaian tujuan pembelajaran tentunya pendidik tidak 
mengabaikan perbedaan potensi yang dimiliki setiap anak. Dalam teori multiple intelligences sangat bagus dan sesuai untuk diaplikasikan dalam pembelajaran anak usia dini. Hal ini disebabkan pada masa usia dini merupakan masa yang sangat cemerlang untu mengetahui berbagai perkembangan anak.

Pembelajaran pada anak usia dini hendaknya didesain menggunakan multiple intelligences sebagai stateginya. Strategi disini sebagai langkah - langkah dalam menyampaikan materi yang disesuaikan dengan kecenderung kecerdasaan anak. Dengan cara ini anak akan lebih mudah dan aktif dalam mengikuti kegiatan pembelajaran.

Dalam konsep multiple intelligences percaya bahwa tidak ada anak yang bodoh, sebab setiap anak pasti memiliki minimal satu kecerdasan yang bisa diasah. Oleh karena itu, dalam mengimplementasikan multiple intelligences pada kegiatan pembelajaran anak usia dini, tentunya pendidik memandang bahwa setiap anak mempunyai gaya belajar yang berbeda. Setiap guru harus mempunyai pandangan dan berpedoman pada prinsip bahwa tidak ada anak yang bodoh. Semua anak dapat belajar dan meningkatkan prestasi belajarnya, manakala anak telah menemukan gaya belajar terbaiknya sesuai dengan kecenderungan kecerdasan yang dimiliki.

Multiple intelligence adalah sebuah penilaian yang melihat secara deskriptif bagaimana individu menggunakan kecerdasannya untuk memecahkan masalah dan menghasilkan sesuatu. Pendekatan ini merupakan alat untuk melihat bagaimana pikiran manusia mengoperasikan dunia, baik itu benda-benda yang konkret maupun hal-hal yang abstrak. Bagi Gardner tidak ada anak yang bodoh atau pintar, yang ada anak yang menonjol dalam salah satu atau beberapa jenis kecerdasan. Dengan demikian, dalam menilai dan menstimulasi kecerdasan anak, orangtua dan guru selayaknya dengan jeli dan cermat merancang sebuah metode khusus. Beberapa materi program yang dapat mengembangkan kecerdasan majemuk akan dipaparkan dalam bentuk tabel di bawah ini.

Tabel 1

Kegiatan Pengembangan Kecerdasan Majemuk

\begin{tabular}{|l|l|}
\hline \multicolumn{1}{|c|}{ Jenis Kecerdasan } & \multicolumn{1}{c|}{ Materi dan Kegiatan } \\
\hline Kecerdasan Linguistik & - Mengajak anak berbicara \\
& - Membacakan cerita \\
& - Bermain huruf \\
& - Merangkai cerita \\
& - Berdiskusi dan bercakap-cakap \\
& - Memperdengarkan lagu anak-anak \\
\hline Kecerdasan Logika- & - Bermain puzzle \\
Matematika & - Mengenal bentuk geometri \\
& - Mengenalkan bilangan melalui sajak berirama dan \\
\hline
\end{tabular}




\begin{tabular}{|c|c|}
\hline 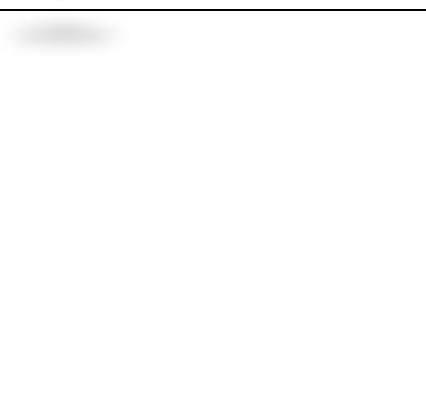 & $\begin{array}{ll} & \text { lagu } \\
\text { - } & \text { Eksplorasi pikiran melalui diskusi dan olah pikir } \\
& \text { ringan } \\
\text { - } & \text { Pengenalan pola } \\
\text { - } & \text { Eksperimen di alam } \\
\text { - } & \text { Memperkaya pengalaman berinteraksi dengan } \\
\text { - } & \text { konsep matematika } \\
\text { - Games penuh strategi dan eksperimen }\end{array}$ \\
\hline $\begin{array}{l}\text { Kecerdasan } \\
\text { Fisik-Kinestetik }\end{array}$ & $\begin{array}{l}\text { - } \text { Menari } \\
\text { - } \text { Bermain peran } \\
\text { - Drama } \\
\text { - } \text { Latihan fisik } \\
\text { - Pantomim } \\
\text { - Berbagai olah gerak }\end{array}$ \\
\hline $\begin{array}{l}\text { Kecerdasan } \quad \text { Visual } \\
\text { Spasial }\end{array}$ & $\begin{array}{l}\text { - Menggambar dan melukis } \\
\text { - Mencorat-coret } \\
\text { - } \text { Membuat prakarya } \\
\text { - Mengunjungi berbagai tempat } \\
\text { - Melakukan permainan konstruktif dan kreatif } \\
\text { - Menagtur dan merancang }\end{array}$ \\
\hline $\begin{array}{l}\text { Kecerdasan } \\
\text { Intrapersonal }\end{array}$ & 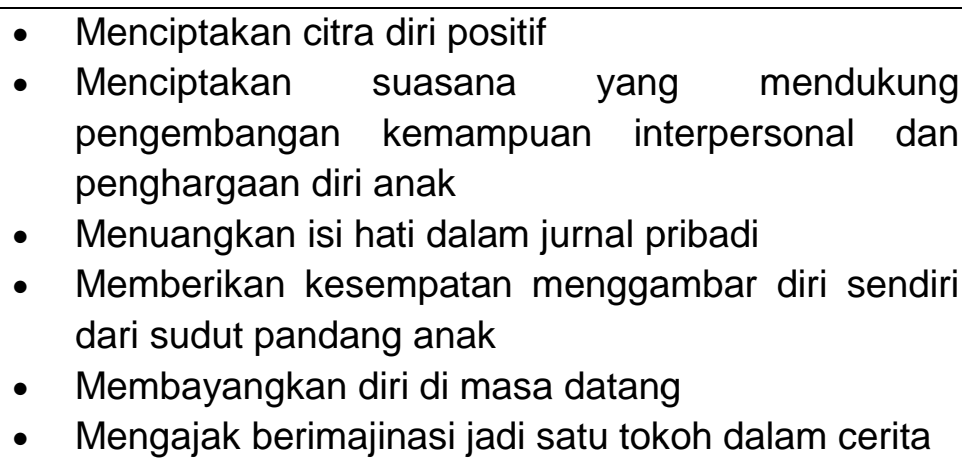 \\
\hline Kecerdasan Musikal & $\begin{array}{l}\text { - Memberi kesempatan pada anak untuk memainkan } \\
\text { - Mengembangkan pemahaman anak tenatng musik } \\
\text { - Memberikan stimulus-stimulus ringan pada anak } \\
\text { agar lebih termotivasi pada bidang musik } \\
\text { - Memberikan pengalaman empiris yang praktis, } \\
\text { seperti memberikan penghargaan terhadap karya } \\
\text { anak, misalnya membuat pentas seni. }\end{array}$ \\
\hline Kecerdasan Natural & $\begin{array}{l}\text { - Melakukan kegiatan sains permulaan, ilmu botani, } \\
\text { gejala-gejala alam atau hubunagn antara benda- }\end{array}$ \\
\hline
\end{tabular}




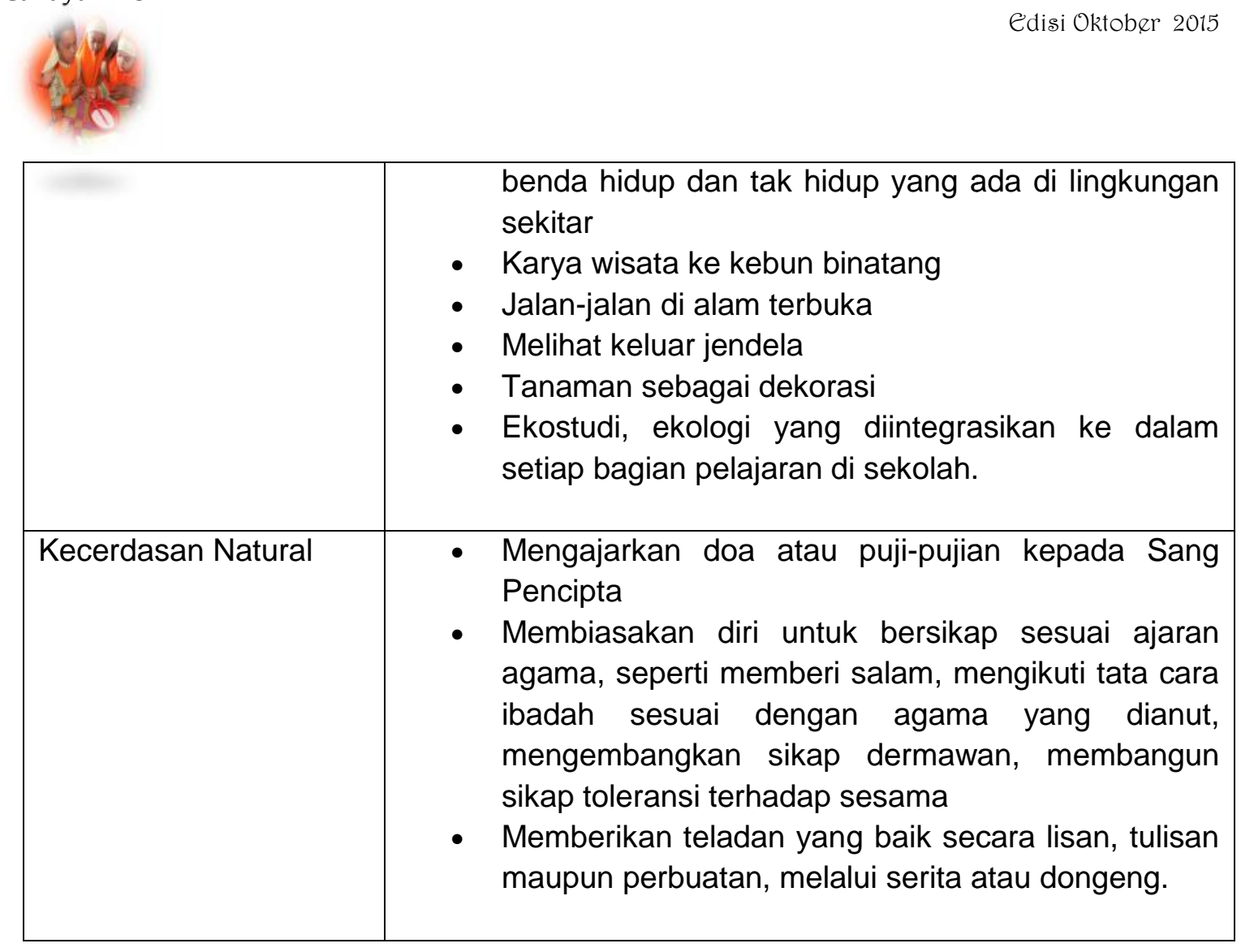

\section{KESIMPULAN}

Setiap individu tidak hanya memiliki satu kecerdasan tetapi lebih yaitu disebut juga multiple intelligences atau kecerdasan ganda. Kecerdasan adalah sehimpunan kemampuan dan keterampilan yang dimiliki individu.Kecerdasan dapat ditingkatkan dengan cara belajar yang mengembangkan kemampuan secara penuh. Multiple intelligence adalah sebuah teori yang dikemukakan oleh Howard Gardner sebagai hasil dari penelitian Project Zero di Amerika. Teorinya menghilangkan anggapan yang ada selama ini tentang kecerdasan manusia. Hasil penelitinaya menunjukan bahwa tidak ada satuan kegiatan manusia yang hanya menggunakan satu macam kecrdasan. Howard Gardner mengemukakan 10 macam kecerdasan, antara lain: kecerdasan verbar/bahasa (verbal linguistic intelligence), kecerdasa logika/matematika (logical/mathematical intelligence), kecerdasan visual/ruang (visual/spatial intelligence, kecerdasan tubuh/gerak tubuh (body/kinesthetic intelligence), kecerdasan musical/ritmik (musical/rhythmic intelligence), kecerdasan interpersonal (interpersonal intelligence), kecerdasan intrapersonal (intrapersonal intelligence), kecerdasan naturalis (naturalisticintelligence), kecerdasan spiritual (spiritual intelligence), dan kecerdasan eksistesial (exsistensialist intelligence).

Banyak murid yang mengalami kebingungan daam menerima pelajaran dan tidak mampu mencerna materi yang diberikan. Dan justru mereka yang dituduh "bermasalah". Ternyata ini hanya masalah ketidaksesuaian gaya mengajar guru dan gaya belajar siswa. Padahal, apabila gaya mengajar guru seuai dengan gaya belajar 
siswa, semua pelajaran akan terasa mudah dan menyenangkan.Berikut adalah yang dihadirkan dalam Multiple Intelligences :

- PenerapanMultiple Intelligences sejatinya

- Penerimaan siswa baru tanpa tes, tetapi melalui metode MIR (Multiple Intelligences Research)

- Mendeteksi gaya belajar

- Mengenali dan melejitkan setiap kecerdasan anak

- Bagaimana membuat guru semain kreatif dengan lesson plan-nya

- Memudahkan pembelajaran

- Mengubah "siswa bermasalah" menjadi berpotensi

- Memperkaya orang tua dan penggiat pendidikan

- Membuat sekolah menjadi unggul

\section{DAFTAR PUSTAKA}

Munif Chatib, Sekolahnya Manusia: Sekolah Berbasis Multiple Intelligences di Indonesia, Kaifa PT Mizan Pustaka : Bandung, 2009.

http://google.com

http://edukasi.kompasiana.com/2014/05/07/pendidikan-anak-usia-dini-berbasis-multipleintelligences-654206.html

http://edukasi.kompasiana.com/2014/06/13/peran-multiple-intelligences-dalampembelajaran-anak-usia-dini--661710.html 